\title{
An overview of the effects of annexin 1 on cells involved in the inflammatory process
}

\author{
Ahmad M Kamal, RoderickJ Flower, Mauro Perretti ${ }^{+}$
}

\begin{abstract}
The William Harvey Research Institute, Bart's and the London Queen Mary School of Medicine and Dentistry, Charterhouse
\end{abstract} Square, London EC1M 6BQ, UK

The concept of anti-inflammation is currently evolving with the definition of several endogenous inhibitory circuits that are important in the control of the host inflammatory response. Here we focus on one of these pathways, the annexin 1 (ANXA1) system. Originally identified as a $37 \mathrm{kDa}$ glucocorticoid-inducible protein, ANXA1 has emerged over the last decade as an important endogenous modulator of inflammation. We review the pharmacological effects of ANXA1 on cell types involved in inflammation, from blood-borne leukocytes to resident cells. This review reveals that there is scope for more research, since most of the studies have so far focused on the effects of the protein and its peptido-mimetics on neutrophil recruitment and activation. However, many other cells central to inflammation, e.g. endothelial cells or mast cells, also express ANXA1: it is foreseen that a better definition of the role(s) of the endogenous protein in these cells will open the way to further pharmacological studies. We propose that a more systematic analysis of ANXA1 physio-pharmacology in cells involved in the host inflammatory reaction could aid in the design of novel anti-inflammatory therapeutics based on this endogenous mediator.

Key words: inflammation - pharmacology - glucocorticoids - lipocortin 1 - receptor

\section{Background}

It is now well appreciated that, during the host inflammatory response, there are several endogenous anti-inflammatory pathways that operate to down-regulate and maintain under control over this response. Thus, the concept of anti-inflammation has recently been developed, to describe the balance that exists between pro-inflammatory pathways and anti-inflammatory mediators that operate in concert to initiate, maintain, and finally resolve the inflammatory reaction. Anti-inflammatory mediators can operate at several stages of the inflammatory response such that blockade of their actions or ablation of their presence by means of gene deletion can produce an inflammatory response of higher intensity or of more prolonged duration (Fig. 1). Besides functioning in inhibitory circuits which dampen specific inflammatory responses (e.g. oedema formation or leukocyte recruitment), anti-inflammatory agonists can also activate apoptosis itself as well as phagocytosis of apoptotic cells; such effects ensure the normally transient nature of the inflammatory response. Finally, another important concept is that anti-inflammation is an active phenomenon such that a given anti-inflammatory mediator will in turn activate target cells to switch to an anti-inflammatory phenotype.

There are several examples of anti-inflammatory agonists including low molecular weight molecules, ranging from adenosine to lipoxins, and more complex substances, from galectins to melanocortins (Perretti 1997, McMahon

Financial support: Wellcome Trust, Arthritis Research Campaign, UK

${ }^{+}$Corresponding author. E-mail: M.Perretti@qmul.ac.uk

Received 8 November 2004

Accepted 30 December 2004 et al. 2001, Lawrence et al. 2002, Catania et al. 2004, Gilroy et al. 2004). Historically, the first anti-inflammatory mediator to be identified and exploited for therapeutic use was cortisol. The seminal work of Hench and colleagues (1949) revealed the pivotal role of cortisol in man, and corticosterone in rodents, as a regulator of the symptoms of several chronic inflammatory pathologies. In the late 1970's, Allan Munck et al. (1984), after reviewing all experimental data obtained with the use of natural and synthetic glucocorticoids, proposed that endogenous glucocorticoids (GC) had the major function of preventing the host inflammatory reaction from over-activation. Therefore, these hormones are endogenously released to ensure the inflammatory response subsides and causes the least damage to the host. These investigations have led to the widespread and sometimes life-saving use of synthetic GC derivatives which mimic the action of the endogenous anti-inflammatory mediator (or hormone in this case).

In the present review we focus on annexin 1 (ANXA1) as an anti-inflammatory mediator. Originally identified as a GC-inducible $37 \mathrm{kDa}$ protein and termed lipocortin (Di Rosa et al. 1984), ANXA1 inhibited phospholipase $A_{2}$ $\left(\mathrm{PLA}_{2}\right)$ activity and hence prostaglandin $(\mathrm{PG})$ generation from perfused lungs and activated macrophages (Flower 1988). The protein was cloned in 1986 (Wallner et al. 1986) and subsequently shown to inhibit the acute inflammatory response (Cirino et al. 1989). Further work indicated that the full-length protein or peptido-mimetics derived from the $\mathrm{N}$-terminal region, retained anti-inflammatory activity in models insensitive to inhibitors of lipid metabolism (Perretti et al. 1993a, Perretti \& Flowers 1993). These pharmacological studies opened the way to further work highlighting the novel effects of this protein on several blood cell types. Furthermore, passive immunisation strategies (Perretti et al. 1996a) and the development of ANXA1 null mice (Hannon et al. 2003) have allowed a better definition of the roles played by the en- 

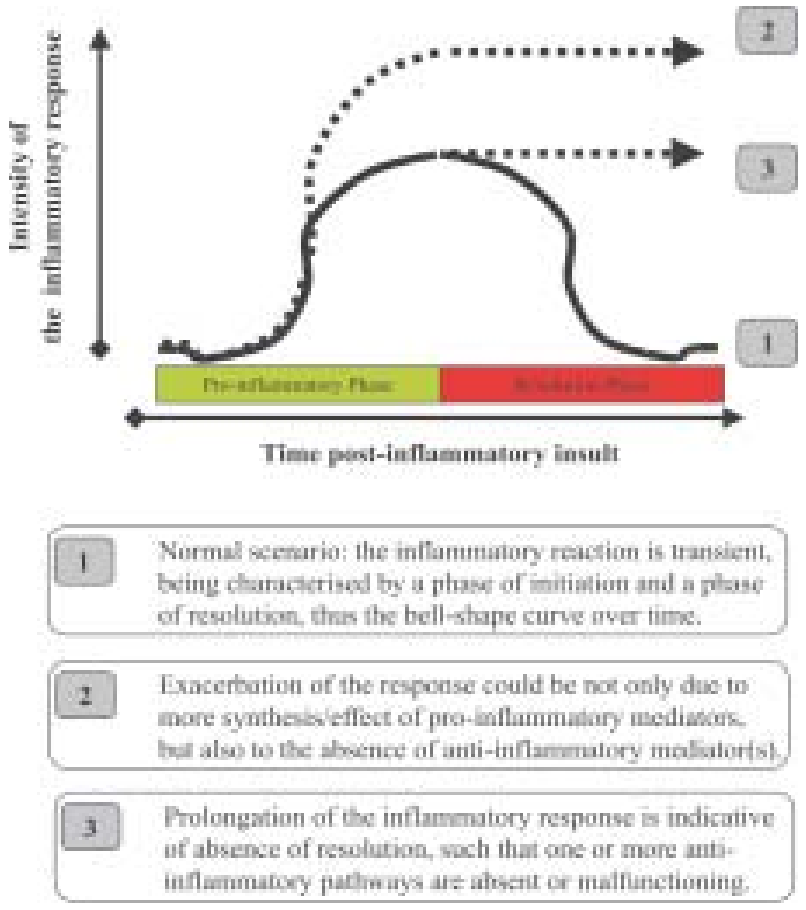

Fig. 1: the concept of resolution and inflammatory pathology. This scheme summarises the concept behind the study of antiinflammation. It is proposed that the physiological scenario (1) is observed when a pro-inflammatory phase of inflammation is followed by an active phenomenon of resolution. Inflammatory pathology could be due to an overshooting of the pro-inflammatory phase (2) or by a lack of active resolution, with consequent prolongation of the inflammatory aetiology and symptoms (3). It is worth noting that scenario no. 2 could also due, at least in part, by lack of activity of anti-inflammatory mediators, tonically active to down-regulate the pro-inflammatory phase (classical example being the one of glucocorticoids, in view of the exacerbation of the response observed after adrenalectomy (Flower et al. 1986, Perretti et al. 1989).

dogenous protein in several cellular functions, including phagocytosis, extravasation, and mediator generation. Over the past decade, our own studies have detailed the mobilization and the function that this protein plays with respect to the process of neutrophil recruitment, so much that we now refer to the "annexin 1 system" as an endogenous biochemical process that operates in the context of the adherent, extravasating neutrophil (Perretti 2003). However, it is well accepted that ANXA1 can affect several other cell types and systems as well, as recently reviewed (John et al. 2004, Parente et al. 2004, Perretti \& Flower 2004). In the present review, we will restrict our analysis to the pharmacological actions reported for exogenously administered ANXA1 or peptido-mimetics (e.g. the $\mathrm{N}$-terminal derived peptide Ac2-26) to cells relevant to the inflammatory process.

\section{ANXA1 actions on monocytes and macrophages}

ANXA1 has been shown to be expressed by many different tissue specific macrophages including alveolar (Ambrose et al. 1992, De Caterina et al. 1993), peritoneal (Peers et al. 1993), and synovial macrophages (Yang et al.
1998) as well as microglial cells (Minghetti et al. 1999), suggesting a regulatory role for the molecule in macrophage activity in general, that is not confined to any given tissue type. The constitutive expression of ANXA1 mRNA and protein by macrophages has been shown reproducibly by many authors to increase following exposure to GC in vitro and in vivo (Ambrose et al. 1992, De Caterina et al. 1993, Peers et al. 1993, Coméra et al. 1995, Perretti \& Flower 1996, Yang et al. 1998, Hall et al. 1999).

The GC responsiveness of monocyte-derived cells is dependent upon their differentiation status. Terminally differentiated macrophages such as human alveolar macrophages synthesise increased amounts of ANXA1 in response to GC treatment both in vitro (Ambrose et al. 1992) and in vivo (De Caterina et al. 1993) when compared to their peripheral blood monocyte precursors. Cellular sensitivity to GC therefore, is acquired during differentiation from blood monocyte to tissue macrophage and has been modelled in human U-937 monocytic cell lines, where GC induction of ANXA1 is only achieved when these cells are differentiated with phorbol ester (Solito et al. 1991).

Whilst endogenous ANXA1 is modulated by GC treatment, several studies have examined the role of exogenous ANXA1 and its derived peptides on various aspects of monocyte and macrophage inflammatory activity. Similar to neutrophil recruitment, the ANXA1-derived peptide Ac2-26 down-regulates the accumulation of monocytes in zymosan-induced peritonitis (though repeated administrations were required), as well as inhibiting the phagocytic activity of resident peritoneal macrophages (Getting et al. 1997). However, recombinant ANXA1 inhibited the adhesion of U-937 monocytic cells to bone marrowderived microvascular endothelial cells, an effect that is mediated by the $\alpha_{4} \beta_{1}$ integrin (Solito et al. 2000). Furthermore, studies using U-937 cells over expressing ANXA1 demonstrated a reduced trans-endothelial migration in response to a specific chemokine in vitro and an inhibition of cell accumulation in rheumatoid synovial grafts transplanted into SCID mice (Perretti et al. 2002b). Interestingly, U-937 cells transfected with an ANXA1 sense construct were more susceptible to both spontaneous and TNF- $\alpha$-induced apoptosis (Solito et al. 2001). Similar studies using stably transfected RAW 264.7 murine macrophages, showed that over-expression of ANXA1 results in constitutive activation of Erk, but not other related MAP kinases, P38 and c-Jun N-terminal kinase resulting in an inhibition of cellular proliferation (Alldridge et al. 1999). These effects were shown to occur via disruption of the actin cytoskeleton and involved the adaptor protein Grb2 in the ANXA1-mediated effect on Erk activation (Alldridge et al. 2003).

There are numerous studies establishing that macrophage-derived inflammatory mediators can be inhibited by GC in an ANXA1-dependent manner by the application of immunoneutralisation strategies, including TNF- $\alpha$ and $\mathrm{PGE}_{2}$ release from human PBMC (Sudlow et al. 1996) and nitric oxide generation by rat synovial macrophages (Yang et al. 1998). In a single study, human recombinant ANXA1, as well as ANXA1 purified from human peripheral blood mononuclear cells (PBMC) or mouse lung inhibited iono- 
phore-stimulated supoeroxide release by guinea pig alveolar macrophages (Maridonneau-Parini et al. 1989), however, such studies using the naturally occurring protein are rare and likely reflect the difficulty in obtaining pure and biologically functional ANXA1. Use of more stable, short N-terminal derived peptides has helped overcome this problem. Indeed, peptide Ac2-26 inhibited phagocytosis of immune complexes (Goulding et al. 1998) as well as superoxide generation (Euzger et al. 1999) by human monocytes.

Several authors have reproducibly shown an inhibitory effect of exogenous ANXA1 on the macrophage nitric oxide system. Dexamethasone-induced synthesis of annexin-like proteins by J774 murine macrophages inhibited LPS-induced nitric oxide production and expression of inducible nitric oxide synthase (D'Acquisto et al. 1997). Similar studies with J774 cells showed identical results using a truncated peptide fragment of ANXA1, residues 1-188 when pre-incubated for $1 \mathrm{~h}$ prior to LPS challenge (Wu et al. 1995) and with recombinant ANXA1 and peptide Ac2-26 in J774 cells (Ferlazzo et al. 2003) and LPSprimed primary rat alveolar macrophages (Kamal et al. 1998). Interestingly, inhibition of nitric oxide release and inducible nitric oxide synthase expression by recombinant ANXA1 were associated with dose and time-dependent increases in IL-10 protein and a concomitant reduction in IL-12 mRNA (Ferlazzo et al. 2003) providing new insights in to the potential mechanism of inhibition of nitric oxide synthesis in macrophages.

\section{ANXA 1 actions on lymphocytes}

Despite the well-documented biological activity of ANXA1 with respect to neutrophil and monocyte/macrophage pro-inflammatory activity, there is as yet sparse information regarding the role of ANXA1 in lymphocyte function. Human (Goulding et al. 1996b) and murine (Perretti et al. 1993b) lymphocytes do not appear to possess binding sites/receptors for ANXA1 and express only modest amounts of the protein (Morand et al. 1995, Perretti \& Flower 1996). Human B-lymphocytes do not seem to express ANXA1 at all, whereas one lymphocyte subset, $\mathrm{CD}^{+} 6^{+}$natural killer cells, express a large amount of ANXA1 (Morand et al. 1995).

Most studies investigating the effects of exogenous ANXA1 on lymphocytes have focussed on the anti-proliferative activity of the molecule. Recombinant ANXA1 and peptides derived from its primary sequence have been shown to exhibit anti-proliferative activity on mitogenstimulated T cell lines and human PBMC. Purified ANXA1 suppresses the proliferation of murine thymocytes (Hirata et al. 1983), and recombinant ANXA1 and the synthetic peptide antiflamin-2 (AF-2; corresponding to amino acid sequence 246-254) inhibit IL-1-stimulated activity in murine Th2-like cell lines (Sierra-Honigmann et al. 1992). Recombinant ANXA1 also demonstrates anti-proliferative activity in mitogen-stimulated human PBMC cultures (Almawi et al. 1996, Koseki et al. 1997). In addition to mitogen-driven lymphocyte proliferation, ANXA1 can also modulate antigenically stimulated T-lymphocytes. Activation of rat myelin basic protein-specific $\mathrm{T}$ cell lines by autologous antigen presenting cells was inhibited by prior incubation of the latter cells with human recombinant ANXA1, whereas ANXA1 was ineffective at inhibiting IL-2-driven proliferation of these T cell lines subsequent to antigen-specific activation (Gold et al. 1996). Such findings suggest that ANXA1 exerts an anti-proliferative effect by specifically interfering with the process of antigen presentation. This is supported by studies demonstrating inhibition of antigen-driven human Th1 and Th2-like cell line proliferation by the ANXA1 N-terminal peptide Ac2-26 and AF-2, where the inhibitory effects of the peptides are lost when proliferation is induced by lectins such as PHA (Kamal et al. 2001). Interestingly, despite these potent effects on T lymphocyte proliferation, ANXA1 does not appear to modulate the expression of lymphocyte adhesion molecules such as CD2 and LFA-1 (Goulding et al. 1999).

\section{ANXA 1 actions on polymorphonuclear leukocytes}

The pharmacological effects of ANXA1 on the neutrophil are probably the best characterised. This is particularly true for in vivo models of neutrophil recruitment (see Perretti 1998 for a review) as well as for models of pathology in which movement of blood-borne neutrophils occurs (Cuzzocrea et al. 1997, Yang et al. 1997, D'Amico et al. 2000, La et al. 2001).

Until recently, there have been few investigations on the direct effects of ANXA1 on neutrophils in vitro. An initial study with human neutrophils demonstrated the ability of peptide Ac2-26 to inhibit cell activation as assessed by arachidonate release, enzyme release and adhesion to endothelial monolayers irrespective of the stimulus applied (Perretti et al. 1995). Some if not all of these effects have also been reported for ANXA1 as well as for AF-2 (Zouki et al. 2000). Thus, it seems that at least two distinct regions of the ANXA1 sequence are able to mimic the inhibitory actions of the parent molecule on the neutrophil. Another interesting study has recently opened a new approach to ANXA1 biology. Walther et al. (2000) have described the ability of peptide Ac2-26 to cause transient calcium fluxes and L-selectin shedding in human neutrophils. These effects were associated with a reduced degree of cell transmigration in vitro. More importantly, with the use of non-selective antagonists and transfection systems, these in vitro analyses indicated a functional interaction between the ANXA1-derived peptide and the receptor for formyl peptides (FPR) (Walther et al. 2000). However, as is the case with many aspects of ANXA1 biology, the situation is quite complex. Human FPR is the proto-type of a family of seven trans-membrane $\mathrm{G}$ protein coupled receptors, with two other members identified to date, FPR-like-1 (FPRL-1) and FPR-like2 (FPRL-2) (Le et al. 2002). Subsequent in vitro and in vivo experimentation, not only with peptide Ac2-26 but also with human recombinant ANXA1, supported a direct interaction with FPRL-1, also known as the lipoxin $\mathrm{A}_{4}$ receptor (ALXR) (Perretti et al. 2002a). In addition to binding assays showing competition between lipoxin $\mathrm{A}_{4}$, ANXA1, and N-terminal-derived peptides [as well as with human serum amyloid A, another agonist for this receptor (Su et al. 1999)], a direct protein:protein interaction between endogenous ANXA1, and ALXR was also ob- 
served as shown by immunoprecipitation (Perretti et al. 2002a). The issue of the ANXA1 receptor or receptors requires further investigation, since the cell and tissue distribution of this family of receptors shows considerable variation, at least in the mouse (Gao et al. 1998). In any case, it is clear that identification of a specific receptor target can facilitate the development of ANXA1 mimetics. With respect to the human neutrophil, the current understanding would suggest that ALXR appears to be a good potential candidate.

Irrespective of the molecular target, the ability of peptide Ac2-26 to cause transient calcium fluxes and L-selectin shedding in human neutrophils (Walther et al. 2000) has also been confirmed for human recombinant ANXA1. Cell incubation with peptide Ac2-26, ANXA1 and a chimeric protein containing the ANXA1 N-terminal region attached to the core domains of ANXA5, also produced transient calcium fluxes and L-selectin shedding (Solito et al. 2003), as well as the first demonstration of ANXA1-driven apoptosis in human neutrophils. Linked to the effects seen with U-937 cells (discussed above in the monocyte/ macrophage section), ANXA1-induced neutrophil apoptosis may have a major impact on the action of this mediator in the context of acute and chronic inflammation (Solito et al. 2003). Again, a new and hitherto unappreciated aspect of ANXA1 biology may be explored as a result of these observations. For instance, experimental evidence in animal models as well as in humans indicated marked presence of ANXA1 in inflammatory exudates (Ambrose et al. 1990b, Smith et al. 1990, Vergnolle et al. 1995, Perretti et al. 1999), suggesting a physiological role for ANXA1 in modulating neutrophil survival at sites of inflammation. In situ hybridization analysis showed de novo ANXA1 synthesis in extravasated neutrophils (Oliani et al. 2001a) supporting the concept of feedback control on neutrophil activity. Clearly, any effect favouring neutrophil apoptosis or removal of apoptotic cells promotes mechanisms of anti-inflammation and activates pathways crucial to control the host inflammatory response (Ward et al. 1999).

Not many studies have investigated ANXA1 effects in the eosinophil. Human eosinophils express ANXA1 though at a lower level compared to the neutrophil (Oliani et al. 2001b, 2002). Rodent models suggest a lack of involvement for endogenous ANXA1 in the GC inhibitory actions on eosinophil trafficking in response to allergen challenge (Das et al. 1997) or chemokine application (Teixeira et al. 1998). However, it is likely that more investigations are required, perhaps on other species or with human cells in vitro, before discarding any function for ANXA1 on this leukocyte type. Interestingly, treatment of human eosinophils with the GC fluticasone produces ANXA1 externalization and this is functionally and temporally related to inhibition of phospholipase $\mathrm{A}_{2}$ translocation into the nucleus and leukotriene release (Sano et al. 1999). Finally, the analogies between ANXA1 and lipoxin $\mathrm{A}_{4}$ described in the neutrophil (and discussed above) together with the receptor-mediated effects of this lipid on eosinophil trafficking (Bandeira-Melo et al. 2000), imply a need for a more systematic investigation.

\section{ANXA 1 actions on other cells}

In this final section we briefly review the relatively few studies that have investigated the physio-pharmacological role of the ANXA1 system in other cells relevant to the inflammatory process. The paucity of experimental data should not be taken as an indication of lack of efficacy, but rather, should favour future novel investigations. The fact that endothelial cells, epithelial cells, mast cells and synoviocytes express ANXA1 suggests a functional role for this protein in these cells. It remains to be seen if these putative effects could also be replicated with pharmacological treatment with ANXA1 or its mimetic.

Endothelial cell - This cell type expresses ANXA1, in part with a nuclear localization (Raynal et al. 1992). The protein does not seem to be mobilized during the short time frame (15-30 min) of the neutrophil adhesion assays (Perretti et al. 1996b), however it is possible that changes may be evident over longer periods. For instance, in an in vivo model of inflammation, endothelial ANXA1 levels increase following neutrophil diapedesis as observed 4 hours post-carrageenin injection (Oliani et al. 2001a). Even less has been done in terms of endothelial cell functions. Two studies demonstrated the lack of effect of ANXA1 and its peptides (both Ac2-26 and AF-2) on endothelial cell adhesion molecule expression, despite reporting their ability to inhibit neutrophil adhesion molecule expression (hence cell adhesion) in co-culture conditions (Perretti et al. 1995, Zouki et al. 2000). However, another study has reported that AF-2 inhibits prostanoid generation by an endothelial cell line (ECV340 cells) stimulated with lipopolysaccharide (Moreno 2001).

Epithelial cell - Prompted by the original observation that epithelial cells express ANXA1 which could be modulated by GC treatment (Ambrose et al. 1990a), most studies have analysed ANXA1 effects on A549 cells, an epithelial lung adenocarcinoma cell line, reminiscent of lung type II epithelial cells. Similar to the lymphocyte data discussed above, most studies on ANXA1 and A549 cells have focused on cell proliferation. In this context, the protein was shown to possess antiproliferative actions and mediated the anti-proliferative effects of GC (Croxtall et al. 1992). The model proposed was that GC addition to A549 cells resulted in ANXA1 translocation to the membrane compartment and subsequent externalization: the membrane-bound pool of the protein inhibited prostaglandin release by affecting cytosolic phospholipase $\mathrm{A}_{2}$ activation through an effect of epidermal growth factor signalling, thereby blocking cell proliferation (Croxtall et al. 1992, 1994). There was no indication of a receptor mediated-mechanism however it is of interest that most if not all of these effects could be reproduced with peptides drawn from the ANXA1 N-terminal region (Croxtall et al. 1993, 1998). Recent indication suggest that the effects of peptide Ac2-26 on A549 cells are also mediated by FPR (Rescher et al. 2002), though the question of the specific receptor mechanism responsible for ANXA1 effects remains open also on this cell type (Perretti 2003).

Mast cell - This important resident cell, often found in the perivascular tissue, expresses ANXA1. The level of 
expression is not marked (especially if compared to neutrophils or epithelial cells) but it can be modulated by GC (Oliani et al. 2000). Importantly, inflammation increases ANXA1 expression with a peculiar pattern of expression, i.e. formation of clusters of immuno-reactivity within specific mast cell cytoplasmic granules (Oliani et al. 2000). Different degrees of ANXA1 expression and susceptibility to modulation by an allergic stimulus has been found between connective tissue and mucosal mast cells (Damazo et al. 2004). Even less is known regarding the role of exogenous ANXA1 on mast cell function. A single study has reported mast cell derived ANXA1 as mediating the stabilising effect of interleukin-2, determined as inhibition of histamine release (Tasaka et al. 1994). Due to the pivotal location of the mast cell and its role not only in initiation but possibly also in resolution of inflammation

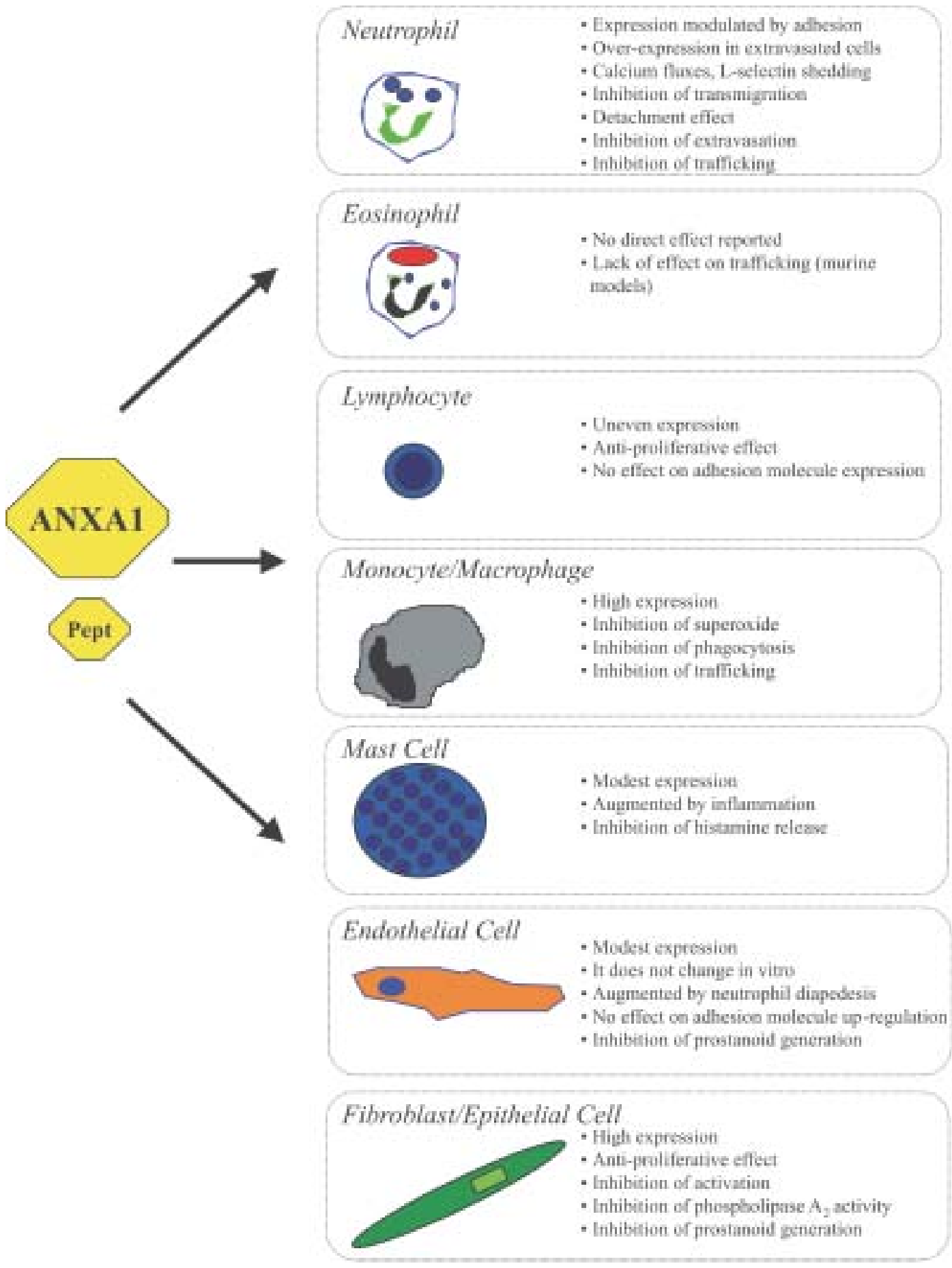

Fig. 2: annexin 1 biology and inflammatory cells. Brief summary of selected biological effects reported for ANXA1 and/or is bioactive peptides on cells relevant to the inflammatory reaction. See text for more details. 
(Kubes et al. 1993, Gotis-Graham et al. 1998, Woolley 2003), it is likely that a role for ANXA1 in this cell type will soon emerge.

Fibroblast/Synoviocyte - The original work of Hirata et al. (1981) described the ability of inhibiting phospholipase $\mathrm{A}_{2}$ activity in stimulated 3T3 mouse fibroblasts by a purified preparation of ANXA1. Subsequent work demonstrated the ability of this cell type to respond to GC incubation with over-expression of ANXA 1 (Phillips et al. 1989). Consistently, anti-ANXA1 antibodies reversed the inhibitory effect of dexamethasone on arachidonate release (Hirata et al. 1981). Activation of human skin fibroblasts provokes intracellular re-location of several annexins, including ANXA1 (Barwise et al. 1996), probably with the ultimate effect of controlling cell activation and lipid metabolism (Errasfa et al. 1985). Recent analysis of the phenotype of ANXA1 null fibroblasts confirms this role for the endogenous protein (Croxtall et al. 2003). The lung-derived fibroblasts lacking ANXA1 display a more elongated phenotype and had augmented arachidonic acid metabolism, due to higher expression of cytosolic phospholipase $\mathrm{A}_{2}$ and cyclo-oxygenase 2 . Ex-vivo analysis of human rheumatoid synovium indicated marked ANXA1 staining in macrophage-like, but not fibroblastlike, synoviocytes (Goulding et al. 1996a); however more recent proteomic approach found detectable ANXA1 levels in fibroblast-like synoviocytes collected from rheumatoid arthritis patients (Dasuri et al. 2004). Finally, in line with the pharmacological data, it is likely that ANXA1 receptor(s) also exist on fibroblasts, since binding of the protein is modulated by cell activation as seen during active disease, e.g. rheumatoid, compared to cells prepared from the synovium of osteoarthritic patients (Sampey et al. 2000).

\section{Conclusion}

We have reviewed here the current knowledge on ANXA1 biology with respect to cells involved in the inflammatory process. Despite brief descriptions of the pattern of expression of ANXA1 and its possible modulation by GC or inflammation, we have tried to place more emphasis on the pharmacological effects that have been ascribed to the protein and/or its peptido-mimetics. With few exceptions (e.g. the neutrophil and perhaps the epithelial cell) it is clear that much more must be done. The convenience of the bioactive ANXA1 N-terminal-derived peptides or the antiflammins could contribute towards defining specific pharmacological effects, that perhaps in the past have been hampered by the lack of recombinant protein. In addition, the recent notion that ANXA1 effects might be mediated by members of the FPR family, possibly ALXR (at least in human systems), may further aid the development of novel therapeutics based on the ANXA 1 pathway.

\section{REFERENCES}

Alldridge LC, Bryant CE 2003. Annexin 1 regulates cell proliferation by disruption of cell morphology and inhibition of cyclin D1 expression through sustained activation of the ERK1/2 MAPK signal. Exp Cell Res 290: 93-107.
Alldridge LC, Harris HJ, Plevin R, Hannon R, Bryant CE 1999. The annexin protein lipocortin 1 regulates the MAPK/ERK pathway. J Biol Chem 274: 37620-37628.

Almawi WY, Saouda MS, Stevens AC, Lipman MK, Barth CM, Strom TB 1996. Partial mediation of glucocorticoid antiproliferative effects by lipocortins. J Immunol 157: 5231-5239.

Ambrose MP, Hunninghake GW 1990a. Corticosteroids increase lipocortin I in alveolar epithelial cells. Am J Resp Cell Mol Biol 3: 349-353.

Ambrose MP, Hunninghake GW 1990b. Corticosteroids increase lipocortin I in BAL fluid from normal individuals and patients with lung disease. Am J Physol 68: 1668-1671.

Ambrose MP, Bahns C-L, Hunninghake GW 1992. Lipocortin I production by human alveolar macrophages. Am J Resp Cell Mol Biol 6: 17-21.

Bandeira-Melo C, Bozza PT, Diaz BL, Cordeiro RS, Jose PJ, Martins MA, Serhan CN 2000. Cutting edge: lipoxin (LX) A4 and aspirin-triggered 15-epi-LXA4 block allergen-induced eosinophil trafficking. J Immunol 164: 2267-2271.

Barwise JL, Walker JH 1996. Annexins II, IV, V and VI relocate in response to rises in intracellular calcium in human foreskin fibroblasts. J Cell Sci 109: 247-255.

Catania A, Gatti S, Colombo G, Lipton JM 2004. Targeting melanocortin receptors as a novel strategy to control inflammation. Pharmacol Rev 56: 1-29.

Cirino G, Peers SH, Flower RJ, Browning JL, Pepinsky RB 1989. Human recombinant lipocortin 1 has acute local antiinflammatory properties in the rat paw edema test. Proc Natl Acad Sci USA 86: 3428-3432.

Coméra C, Russo-Marie F 1995. Glucocorticoid-induced annexin I secretion by monocytes and peritoneal leukocytes. Br J Pharmacol 115: 1043-1047.

Croxtall JD, Flower RJ 1992. Lipocortin 1 mediates dexamethasone-induced growth arrest of the A549 lung adenocarcinoma cell line. Proc Natl Acad Sci USA 89: 3571-3575.

Croxtall JD, Flower RJ 1994. Antisense oligonucleotides to human lipocortin-1 inhibit glucocorticoid-induced inhibition of A549 cell growth and eicosanoid release. Biochem Pharmacol 48: 1729-1734.

Croxtall JD, Choudhury Q, Flower RJ 1998. Inhibitory effect of peptides derived from the $\mathrm{N}$-terminus of lipocortin 1 on arachidonic acid release and proliferation in the A549 cell line: identification of EQEYV as a crucial component. $\mathrm{Br} J$ Pharmacol 123: 975-983.

Croxtall JD, Gilroy DW, Solito E, Choudhury Q, Ward BJ, Buckingham JC, Flower RJ 2003. Attenuation of glucocorticoid functions in an Anx-A1-/- cell line. Biochem J 371: 927-935.

Croxtall JD, Waheed S, Choudhury Q, Anand R, Flower RJ 1993. N-terminal peptide fragments of lipocortin-1 inhibit A549 cell growth and block EGF-induced stimulation of proliferation. Int J Cancer 54: 153-158.

Cuzzocrea S, Tailor A, Zingarelli B, Salzman AL, Flower RJ, Szabó C, Perretti M 1997. Lipocortin 1 protects against splanchnic artery occlusion and reperfusion injury by affecting neutrophil migration. J Immunol 159: 5089-5097. 
D’ Acquisto F, Cicatiello L, Iuvone T, Ialenti A, Ianaro A, Esumi H, Weisz A, Carnuccio R 1997. Inhibition of inducible nitric oxide synthase gene expression by glucocorticoid-induced protein(s) in lipopolysaccharide-stimulated J774 cells. Eur J Pharmacol 339: 87-95.

D’Amico M, Di Filippo C, La M, Solito E, Mclean PG, Flower RJ, Oliani SM, Perretti M 2000. Lipocortin 1 reduces myocardial ischaemia-reperfusion injury by affecting local leukocyte recruitment. FASEB J 14: 1867-1869.

Damazo A, Paul-Clark MJ, Straus AH, Takahashi HK, Perretti M, Oliani SM 2004. Analysis of annexin 1 expression in rat trachea: study of the mast cell heterogeneity. Annexins, 1, (on line only).

Das AM, Flower RJ, Hellewell PG, Teixeira MM, Perretti M 1997. A novel murine model of allergic inflammation to study the effect of dexamethasone on eosinophil recruitment. BrJ Pharmacol 121: 97-104.

Dasuri K, Antonovici M, Chen K, Wong K, Standing K, Ens W, El-Gabalawy H, Wilkins JA 2004. The synovial proteome: analysis of fibroblast-like synoviocytes. Arthritis Res Ther 6: R161-R168.

De Caterina R, Sicari R, Giannessi D, Paggiaro PL, Paoletti P, Lazzerini G, Bernini W, Solito E, Parente L 1993. Macrophage-specific eicosanoid synthesis inhibition and lipocortin-1 induction by glucocorticoids. J Appl Physiol 75: 2368-2375.

Di Rosa M, Flower RJ, Hirata F, Parente L, Russo-Marie F 1984. Nomenclature announcement. Anti-phospholipase proteins. Prostaglandins 28: 441-442.

Errasfa M, Rothhut B, Fradin A, Billardon C, Junien JL, Bure J, Russo-Marie F 1985. The presence of lipocortin in human embryonic skin fibroblasts and its regulation by anti-inflammatory steroids. Biochim Biophys Acta 847: 247-254.

Euzger HS, Flower RJ, Goulding NJ, Perretti M 1999. Differential modulation of annexin I binding sites on monocytes and neutrophils. Med Inflamm 8: 53-62.

Ferlazzo V, D'agostino P, Milano S, Caruso R, Feo S, Cillari E, Parente L 2003. Anti-inflammatory effects of annexin-1: stimulation of IL-10 release and inhibition of nitric oxide synthesis. Int Immunopharmacol 3: 1363-1369.

Flower RJ 1988. Lipocortin and the mechanism of action of the glucocorticoids. Br J Pharmacol 94: 987-1015.

Flower RJ, Parente L, Persico P, Salmon JA 1986. A comparison of the acute inflammatory response in adrenalectomised and sham-operated rats. Br J Pharmacol 87: 57-62.

Gao J-L, Chen H, Filie JD, Kozak CA, Murphy PM 1998. Differential expansion of the $\mathrm{N}$-formylpeptide receptor gene cluster in human and mouse. Genomics 51: 270-276.

Getting SJ, Flower RJ, Perretti M 1997. Inhibition of neutrophil and monocyte recruitment by endogenous and exogenous lipocortin 1. Br J Pharmacol 120: 1075-1082.

Gilroy DW, Lawrence T, Perretti M, Rossi AG 2004. Inflammatory resolution: new opportunities for drug discovery. Nat Rev Drug Discov 3: 401-416.

Gold R, Pepinsky RB, Zettl UK, Toyka KV, Hartung H-P 1996. Lipocortin-1 (annexin-1) suppresses activation of autoimmune $\mathrm{T}$ cell lines in the Lewis rat. J Neuroimmunol 69: 157-164.
Gotis-Graham I, Smith MD, Parker A, Mcneil HP 1998. Synovial mast cell responses during clinical improvement in early rheumatoid arthritis. Ann Rheum Dis 57: 664-671.

Goulding NJ, Dixey J, Morand EF, Dodds RA, Pitsillides AA, Edwards JCW 1996a. Differential distribution of annexinsI, -II, -IV, and -VI in synovium. Ann Rheum Dis 54: 841845.

Goulding NJ, Euzger HS, Butt SK, Perretti M 1998. Novel pathways for glucocorticoid effects on neutrophils in chronic inflammation. Inflamm Res 47 (Suppl. 3): S158-S165.

Goulding NJ, Ogbourn, S, Pipitone N, Biagini P, Gerli R, Pitzalis C 1999. The inhibitory effect of dexamethasone on lymphocyte adhesion molecule expression and intercellular aggregation is not mediated by lipocortin 1. Clin Exp Immunol 118: 376-383.

Goulding NJ, Pan L, Wardwell K, Guyre VC, Guyre PM 1996b. Evidence for specific annexin I-binding proteins on human monocytes. Biochemical J 316: 593-597.

Hall SE, Lim, S, Witherden, IR, Tetley TD, Barnes PJ, Kamal AM, Smith SF 1999. Lung type II cell and macrophage annexin I release: differential effects of two glucocorticoids. Am J Physiol 276: L114-L121.

Hannon R, Croxtall JD, Getting SJ, Roviezzo F, Yona S, PaulClark MJ, Gavins FN, Perretti M, Morris JF, Buckingham JC, Flower RJ 2003. Aberrant inflammation and resistance to glucocorticoids in annexin 1-/- mouse. FASEB J 17: 253255 .

Hench PS, Kendall EC, Slocumb CH, Polley HE 1949. The effect of the adrenal cortex (17-hydroxy-11-dehydrocortisone: compound E) and of pituitary adrenocorticotropic hormone on rheumatoid arthritis; preliminary report. Proc Staff Meet Mayo Clin 24: 181-197.

Hirata F, Iwata M 1983. Role of lipomodulin, a phospholipase inhibitory protein, in immunoregulation by thymocytes. $J$ Immunol 130: 1930-1936.

Hirata F, Del Carmine R, Nelson CA, Axelrod J, Schiffman E, Warabi A, De Blas AL, Nireberg M, Manganiello V, Vaughan M, Kumagai S, Green I, Decker JL, Steinberg AD 1981. Presence of autoantibody for phospholipase inhibitory protein, lipomodulin, in patients with rheumatic diseases. Proc Natl Acad Sci USA 78: 3190-3194.

John CD, Christian HC, Morris JF, Flower RJ, Solito E, Buckingham JC 2004. Annexin 1 and the regulation of endocrine function. Trends Endocrinol Metab 15: 103-109.

Kamal AM, Smith SF, De Silva Wijayasinghe M, Solito E, Corrigan CJ 2001. An annexin 1 (ANXA1)-derived peptide inhibits prototype antigen-driven human T cell Th1 and Th2 responses in vitro. Clin Exp Allergy 31: 1116-1125.

Koseki H, Shiiba K-I, Suzuki Y, Asanuma T, Matsuno S 1997. Enhanced expression of lipocortin-1 as a new immunosuppressive protein in cancer patients and its influence on reduced in vitro peripheral blood lymphocyte response to mitogens. Surgery Today Japanese J Surgery 27: 30-39.

Kubes P, Kanwar S, Niu X-F, Gaboury JP 1993. Nitric oxide synthesis inhibition induces leukocyte adhesion via superoxide and mast cells. FASEB J 7: 1293-1299.

La M, D’Amico M, Bandiera S, Di Filippo C, Oliani SM, Gavins FN, Flower RJ, Perretti M 2001. Annexin 1 peptides pro- 
tect against experimental myocardial ischemia- reperfusion: analysis of their mechanism of action. FASEB J 15: 22472256.

Lawrence T, Willoughby DA, Gilroy DW 2002. Anti-inflammatory lipid mediators and insights into the resolution of inflammation. Nat Rev Immunol 2: 787-795.

Le Y, Murphy PM, Wang JM 2002. Formyl-peptide receptors revisited. Trends Immunol 23: 541-548.

Maridonneau-Parini I, Errasfa M, Russo-Marie F 1989. Inhibition of O2- generation by dexamethasone is mimicked by lipocortin I in alveolar macrophages. J Clin Invest 83: 19361940.

McMahon B, Mitchell S, Brady HR, Godson C 2001. Lipoxins: revelations on resolution. Trends Pharmacol Sci 22: 391395.

Minghetti L, Nicolini A, Polazzi E, Greco A, Perretti M, Parente L, Levi G 1999. Down-regulation of microglial cyclo-oxygenase-2 and inducible nitric oxide synthase by lipocortin 1. Br J Pharmacol 126: 1307-1314.

Morand EF, Hutchinson P, Hargreaves A, Goulding NJ, Boyce NW, Holdsworth S 1995. Detection of intracellular lipocortin 1 in human leukocyte subsets. Clin Immunol Immunopathol 76: 195-202.

Moreno JJ 2001. Antiflammin-2 prevents HL-60 adhesion to endothelial cells and prostanoid production induced by lipopolysaccharides. J Pharmacol Exp Ther 296: 884-889.

Munck A, Guyre PM, Holbrook NJ 1984. Physiological functions of glucocorticoids in stress and their relation to pharmacological actions. Endocrine Rev 5: 25-44.

Oliani SM, Perretti M 2001b. Cell localization of the antiinflammatory protein annexin 1 during experimental inflammatory response. Ital J Anat Embryol 106: 69-77.

Oliani SM, Damazo AS, Perretti M 2002. Annexin 1 localisation in tissue eosinophils as detected by electron microscopy. Med Inflamm 11: 287-292.

Oliani SM, Christian HC, Manston J, Flower RJ, Perretti M 2000. An immunocytochemical and in situ hybridization analysis of annexin 1 expression in rat mast cells: modulation by inflammation and dexamethasone. Lab Invest 80 : 1429-1438.

Oliani SM, Paul-Clark MJ, Christian HC, Flower RJ, Perretti M 2001a. Neutrophil interaction with inflamed postcapillary venule endothelium alters annexin 1 expression. Am J Pathol 158: 603-615.

Parente L, Solito E 2004. Annexin 1: more than an anti-phospholipase protein. Inflamm Res 53: 125-132.

Peers SH, Smillie F, Elderfield AJ, Flower RJ 1993. Glucocorticoid- and non-glucocorticoid induction of lipocortins (annexins) 1 and 2 in rat peritoneal leucocytes in vivo. $B r J$ Pharmacol 108: 66-72.

Perretti M 1997. Endogenous mediators that inhibit the leukocyte-endothelium interaction. Trends Pharmacol Sci 18: 418425 .

Perretti M 1998. Lipocortin 1 and chemokine modulation of granulocyte and monocyte accumulation in experimental inflammation. Gen Pharmacol 31: 545-552.

Perretti M 2003. The annexin 1 receptor(s): is the plot unravelling? Trends Pharmacol Sci 24: 574-579.

Perretti M, Flower RJ 1993. Modulation of IL-1-induced neutrophil migration by dexamethasone and lipocortin $1 . J$ Immunol 150: 992-999.

Perretti M, Flower RJ 1996. Measurement of lipocortin 1 levels in murine peripheral blood leukocytes by flow cytometry: modulation by glucocorticoids and inflammation. Br J Pharmacol 118: 605-610.

Perretti M, Flower RJ 2004. Annexin 1 and the biology of the neutrophil. J Leukoc Biol 76: 25-29.

Perretti M, Flower RJ, Goulding NJ 1993b. The ability of murine leukocytes to bind lipocortin 1 is lost during acute inflammation. Biochem Biophys Res Comm 192: 345-350.

Perretti M, Ahluwalia A, Harris JG, Goulding NJ, Flower RJ 1993a. Lipocortin-1 fragments inhibit neutrophil accumulation and neutrophil-dependent edema in the mouse: a qualitative comparison with an anti-CD11b monoclonal antibody. J Immunol 151: 4306-4314.

Perretti M, Ahluwalia A, Harris JG, Harris HJ, Wheller SK, Flower RJ 1996a. Acute inflammatory response in the mouse: exacerbation by immunoneutralization of lipocortin 1. Br J Pharmacol 117: 1145-1154.

Perretti M, Becherucci C, Scapigliati G, Parente L 1989. The effect of adrenalectomy on interleukin-1 release in vitro and in vivo. Br J Pharmacol 98: 1137-1142.

Perretti M, Chiang N, La M, Fierro IM, Marullo S, Getting SJ, Solito E, Serhan CN 2002a. Endogenous lipid- and peptidederived anti-inflammatory pathways generated with glucocorticoid and aspirin treatment activate the lipoxin A4 receptor. Nat Med 8: 1296-1302.

Perretti M, Croxtall JD, Wheller SK, Goulding NJ, Hannon R, Flower RJ 1996b. Mobilizing lipocortin 1 in adherent human leukocytes downregulates their transmigration. Nat Med 22: $1259-1262$.

Perretti M, Ingegnoli F, Wheller SK, Blades MC, Solito E, Pitzalis C 2002b. Annexin 1 modulates monocyte-endothelial cell interaction in vitro and cell migration in vivo in the human SCID mouse transplantation model. J Immunol 169: 2085-2092.

Perretti M, Wheller SK, Choudhury Q, Croxtall JD, Flower RJ 1995. Selective inhibition of neutrophil function by a peptide derived from lipocortin $1 \mathrm{~N}$-terminus. Biochem Pharmacol 50: 1037-1042.

Perretti M, Wheller SK, Flower RJ, Wahid S, Pitzalis C 1999. Modulation of cellular annexin I in human leukocytes infiltrating DTH skin reactions. J Leukoc Biol 65: 583-589.

Phillips C, Rose-John S, Rincke G, Furstenberger G, Marks F 1989. cDNA-cloning, sequencing and expression in glucocorticoid-stimulated quiescent Swiss 3 T3 fibroblasts of mouse lipocortin I. Biochem Biophys Res Comm 159: 155162.

Raynal P, Van Bergen PMP, Hullin F, Ragab-Thomas JMF, Fauvel J, Verkleij A, Chap H 1992. Morphological and biochemical evidence for partial nuclear localization of annexin I in endothelial cells. Biochem Biophys Res Comm 186: 432439.

Rescher U, Danielczyk A, Markoff A, Gerke V 2002. Functional activation of the formyl peptide receptor by a new 
endogenous ligand in human lung A549 cells. J Immunol 169: 1500-1504.

Sampey AV, Hutchinson P, Morand EF 2000. Annexin I surface binding sites and their regulation on human fibroblast-like synoviocytes. Arthritis Rheum 43: 2537-2542.

Sano A, Munoz NM, Sano H, Choi J, Zhu X, Jacobs B, Leff AR 1999. Inhibition of cPLA2 translocation and leukotriene C4 secretion by fluticasone propionate in exogenously activated human eosinophils. Am J Respir Crit Care Med 159: 1903-1909.

Sierra-Honigmann MR, Murphy PA 1992. Suppression of interleukin-1 action by phospholipase-A2 inhibitors in helper T lymphocytes. Pept Res 5: 258-261.

Smith SF, Tetley TD, Guz A, Flower RJ 1990. Detection of lipocortin 1 in human lung lavage fluid: lipocortin degradation as a possible proteolytic mechanism in the control of inflammatory mediators and inflammation. Env Health Perspect 85: 135-144.

Solito E, De Coupade C, Canaider S, Goulding NJ, Perretti M 2001. Transfection of annexin 1 in monocytic cells produces a high degree of spontaneous and stimulated apoptosis associated with caspase-3 activation. Br J Pharmacol 133: 217-228.

Solito E, Kamal AM, Russo-Marie F, Buckingham JC, Marullo S, Perretti M 2003. A novel calcium-dependent proapoptotic effect of annexin 1 on human neutrophils. FASEB J 17: 1544-1546.

Solito E, Raugei G, Melli M, Parente L 1991. Dexamethasone induces the expression of the mRNA of lipocortin 1 and 2 and the release of lipocortin 1 and 5 in differentiated, but not undifferentiated U-937 cells. FEBS Lett 291: 238-244.

Solito E, Romero IA, Marullo S, Russo-Marie F, Weksler BB 2000. Annexin 1 binds to U937 monocytic cells and inhibits their adhesion to microvascular endothelium: involvement of the a4ß1 integrin. J Immunol 165: 1573-1581.

Su SB, Gong W, Gao JL, Shen W, Murphy PM, Oppenheim JJ, Wang JM 1999. A seven-transmembrane, G protein-coupled receptor, FPRL1, mediates the chemotactic activity of serum amyloid A for human phagocytic cells. J Exp Med 189: 395-402.

Sudlow AW, Carey F, Forder R, Rothwell NJ 1996. The role of lipocortin-1 in dexamethasone-induced suppression of PGE2 and TNFa release from human peripheral blood mononuclear cells. Br J Pharmacol 117: 1449-1456.
Tasaka K, Hamada M, Mio M 1994. Inhibitory effect of interleukin-2 on histamine release from rat mast cells. Agents Actions 41: C26-C27.

Teixeira MM, Das AM, Miotla JM, Perretti M, Hellewell PG 1998. The role of lipocortin 1 in the inhibitory action of dexamethasone on eosinophil trafficking in cutaneous inflammatory reactions in the mouse. Br J Pharmacol 123: 538-544.

Vergnolle N, Coméra C, Buéno L 1995. Annexin 1 is overexpressed and specifically secreted during experimentally induced colitis in rats. Eur J Biochem 232: 603-610.

Wallner BP, Mattaliano RJ, Hession C, Cate RL, Tizard R, Sinclair LK, Foeller C, Chow EP, Browning JL, Ramachandran KL, Pepinsky RB 1986. Cloning and expression of human lipocortin, a phospholipase A2 inhibitor with potential anti-inflammatory activity. Nature 320: 7781.

Walther A, Riehemann K, Gerke V 2000. A novel ligand of the formyl peptide receptor: annexin I regulates neutrophil extravasation by interacting with the FPR. Mol Cell 5: 831840.

Ward I, Dransfield I, Chilvers ER, Haslett I, Rossi AG 1999. Pharmacological manipulation of granulocyte apoptosis: potential therapeutic targets. Trends Pharmacol Sci 20: 503509.

Woolley DE 2003. The mast cell in inflammatory arthritis. $N$ Engl J Med 348: 1709-1711.

Wu C-C, Croxtall JD, Perretti M, Bryant CE, Thiemermann C, Flower RJ, Vane JR 1995. Lipocortin 1 mediates the inhibition by dexamethasone of the induction by endotoxin of nitric oxide synthase in the rat. Proc Natl Acad Sci USA 92: 3473-3477.

Yang Y, Leech M, Hutchinson P, Holdsworth SR, Morand EF 1997. Antiinflammatory effect of lipocortin 1 in experimental arthritis. Inflammation 21: 583-596.

Yang YH, Hutchinson P, Santos LL, Morand EF 1998. Glucocorticoid inhibition of adjuvant arthritis synovial macrophage nitric oxide production: role of lipocortin 1. Clin Exp Immunol 111: 117-122.

Zouki C, Ouellet S, Filep JG 2000. The anti-inflammatory peptides, antiflammins, regulate the expression of adhesion molecules on human leukocytes and prevent neutrophil adhesion to endothelial cells. FASEB J 14: 572-580. 
